\title{
Effects of dichlorobenzene on acetylcholine receptors in human neuroblastoma SH-SY5Y cells
}

\author{
Ren-Ming Yan ${ }^{a}$, Yin-Mei Chiung b,c ${ }^{b}$ Chien-Yuan Pan ${ }^{d}$, Jenn-Hwa Liu ${ }^{\mathrm{e}}$, Pei-Shan Liu ${ }^{\mathrm{a}, *}$ \\ a Department of Microbiology, Soochow University, Shihlin, Taipei, Taiwan, ROC \\ ${ }^{\mathrm{b}}$ Division of Occupational Medicine, Institute of Occupational Safety and Health, Taipei, Taiwan, ROC \\ c Department of Microbiology and Immunology, National Defense Medical Center, Taipei, Taiwan, ROC \\ ${ }^{\mathrm{d}}$ Institute of Zoology and Department of Life Science, National Taiwan University, Taipei, Taiwan, ROC \\ e Division of Gastroenterology, Kuang-Tien General Hospital, Taiwan, ROC
}

\section{A R T I C L E I N F O}

\section{Article history:}

Received 1 May 2008

Received in revised form 22 July 2008

Accepted 22 July 2008

Available online 9 August 2008

\section{Keywords:}

Dichlorobenzene

Acetylcholine receptor

Calcium signaling

Human neuroblastoma SH-SY5Y cells

Thapsigargin

\begin{abstract}
A B S T R A C T
para-Dichlorobenzene (DCB), a deodorant and an industrial chemical, is a highly volatile compound and is known to be an indoor air contaminant. Because of its widespread use and volatility, the toxicity of DCB presents a concern to industrial workers and public. Some toxic aspects of DCB have already been focused but its effects on neuronal signal transduction have been hitherto unknown. The effects of DCB on the cytosolic calcium homeostasis are investigated in human neuroblastoma SH-SY5Y cells in this study. DCB, above $200 \mu \mathrm{M}$, was found to induce a rise in cytosolic calcium concentration that could not be counteracted by nicotinic acetylcholine receptor $(\mathrm{nAChR})$ and muscarinic acetylcholine receptor (mAChR) antagonists but was partially inhibited by thapsigargin. To understand the actions of DCB on the acetylcholine receptors, we investigated its effects on the changes of cytosolic calcium concentration following nicotinic AChR stimulation with epibatidine and muscarinic AChR stimulation with methacholine in human neuroblastoma SH-SY5Y cells. DCB inhibited the cytosolic calcium concentration rise induced by epibatidine and methacholine with respective $\mathrm{IC}_{50} \mathrm{~s}$ of 34 and $294 \mu \mathrm{M}$. The inhibitions of DCB were not the same as thapsigargin's inhibition. In the electrophysiological observations, DCB blocked the influx currents induced by epibatidine. Our findings suggest that DCB interferes with the functional activities of AChR, including its coupling influx currents and cytosolic calcium elevations.
\end{abstract}

(c) 2008 Published by Elsevier Ireland Ltd.

\section{Introduction}

para-Dichlorobenzene (DCB) has been widely used as a deodorant and a moth repellent, and as an intermediate for dyestuff, fungicides, pharmaceuticals, and industrial chemicals. DCB is a highly volatile compound, with a vapor pressure of $1 \mathrm{mmHg}$ at $25^{\circ} \mathrm{C}$ (Hayes, 1982) and is an indoor air contaminant (Wallace et al., 1987, 1988, 1989; Hartwell et al., 1992; Kostiainen, 1995). The major portion of DCB used finds its way into the atmosphere (IARC, 1982). Because of its widespread use and volatility, the toxicity of DCB presents a concern to industrial workers and the public. DCB has been detected in adipose tissues (Morita and Ohi, 1975; Jan, 1983),

Abbreviations: $\left[\mathrm{Ca}^{2+}\right]_{\mathrm{c}}$, cytosolic free $\mathrm{Ca}^{2+}$ concentration; DCB, paradichlorobenzene; EPI, epibatidine; AChR, acetylcholine receptor; $\mathrm{nAChR}$, nicotinic acetylcholine receptor; $\mathrm{MAChR}$, muscarinic acetylcholine receptor; VOCC, voltageoperated $\mathrm{Ca}^{2+}$ channel; $\mathrm{IP}_{3}$, inositol triphosphate; CICR, $\mathrm{Ca}^{2+}$-induced $\mathrm{Ca}^{2+}$ release.

* Corresponding author. Tel.: +8862 28819471x6857; fax: +886228831193.

E-mail address: psliu@mail.scu.edu.tw (P.-S. Liu). blood (Morita and Ohi, 1975; Hill et al., 1995) and mothers' milk (Jan, 1983) in the general population, illustrating the widespread human exposure to the compound. In animal studies, DCB causes hepatocarcinogenicity including hepatocellular carcinoma, hepatoblastoma (NTP, 1987), and kidney damage (Steinmetz et al., 1988). The primary route for the contact of DCB is inhalation, and olfactory mucosal lesions induced by DCB had been found (Bahrami et al., 1999). A major DCB metabolite, 2,6-dichlorophenol, has been detected in olfactory bulb and olfactory mucosa, and has been linked to increased glial fibrillary acidic protein in the olfactory bulb of mice (Carlsson et al., 2003). The nasal cavity contains an olfactory neuron, which links with an interneuron and is used to relay information to the brain; therefore, neuronal signal transduction is important. Moreover, the airway possesses neuronal receptors such as the nicotinic acetylcholine receptor (nAChR) and muscarinic acetylcholine receptor ( $\mathrm{MAChR}$ ). The roles of $\mathrm{DCB}$ on $\mathrm{nAChR}$ and $\mathrm{mAChR}$ are also important. However, the effects of DCB on neuronal signal transduction have been hitherto unknown.

DCB has estrogenic effects and affects animal endocrine functions through its action as a xenoestrogen (Versonnen et al., 2003). 
Estrogen not only has long-term genomic effects but also has various non-genomic actions (Chen and Farese, 1999; Kelly and Levin, 2001). These non-genomic effects are characterized by rapid time courses and the modulation of membrane receptors and membrane channels in muscle cells and neuronal cells. Estrogen acts on nAChR (Ke and Lukas, 1996) and mAChR (Cardoso et al., 2004). Using estrogen receptor-mediated estrogenic-like activities as a springboard, some xenoestrogens have been found to act at membrane receptors. AChRs are widely distributed in the nervous system (e.g., muscle, autonomic ganglia, and the central nervous system) (Sastry and Sadavongvivad, 1978) and include nAChR belonging to ligandgated ion channel superfamily of neurotransmitter receptors and $\mathrm{mAChRs}$ belonging to GTP-binding protein coupled receptors. Both nAChR and mAChR play critical roles in brain and body functions (Belmonte, 2005), as well as in developmental processes (Hamassaki-Britto et al., 1994; Grant and Landis, 1991) and are the targets of steroid hormones such as estradiol (Arias, 1998) and endocrine disruptors such as phthalates (Liu and Lin, 2002).

Human SH-SY5Y neuroblastoma cells have a various characteristics of sympathetic ganglion cells and are widely used in the studies of a variety of $\mathrm{Ca}^{2+}$ signaling pathways, including voltagedependent $\mathrm{Ca}^{2+}$ entry and receptor-mediated $\mathrm{Ca}^{2+}$ homeostasis (Lambert et al., 1990; Toselli et al., 1991; Passafaro et al., 1992). The SH-SY5Y cells possess various subtypes of nAChR (Lukas et al., 1993; Ke and Lukas, 1996) and mAChR (Lambert et al., 1990), therefore, these cells represent an ideal system to study not only the function of specific $\mathrm{Ca}^{2+}$ signaling, but also to study the activities of AChRs. Using human SH-SY5Y neuroblastoma cells, the possibility of DCB acting on AChRs was presently investigated.

\section{Material and methods}

\subsection{Chemicals}

DCB, $17 \alpha$-estradiol, carbachol, epibatidine (EPI), methacholine, atropine, digitonin, hexamethonium, thapsigargin, verapamil, deoxyribonuclease I and EGTA were all obtained from Sigma Chemical Co. Fura-2 AM was obtained from Molecular Probes. DCB was dissolved in DMSO first and then diluted (at least 100 folds) into the concentration we used in loading buffer.

\subsection{Cell culture}

The human neuroblastoma SH-SY5Y cells, obtained from ATCC (CRL-2266), were cultured in a minimally essential medium and F12 medium (1:1), supplemented with $10 \%$ fetal bovine serum and $100 \mathrm{U}$ penicillin/streptomycin, and grown in a $5 \%$ $\mathrm{CO}_{2}$ humidified incubator at $37^{\circ} \mathrm{C}$ (Lambert et al., 1990). The medium was changed every 3-4 days and the cells were subcultured every 7 days. The confluent cells were collected to process the cytosolic calcium concentration $\left(\left[\mathrm{Ca}^{2+}\right]_{c}\right)$ measurements.

\section{3. $\left[\mathrm{Ca}^{2+}\right]_{c}$ measurement}

The human neuroblastoma SH-SY5Y cells were loaded with fura- 2 by incubation $\left(5 \times 10^{6}\right.$ cells $\left./ \mathrm{ml}\right)$ with $10 \mu \mathrm{M}$ fura- 2 acetoxymethyl ester at $37^{\circ} \mathrm{C}$ for $30 \mathrm{~min}$. Cells were then washed twice with loading buffer contained (in $\mathrm{mM}$ ) $\mathrm{NaCl} 150 ; \mathrm{KCl} 5$, Glucose 5, $\mathrm{MgCl}_{2} 1, \mathrm{CaCl}_{2}$ 2.2, and HEPES 10, pH 7.4. The cells were stimulated with agonists in the presence or absence of DCB in loading buffer or $\mathrm{Ca}^{2+}$ free loading buffer (containing (in $\mathrm{mM}$ ) $\mathrm{NaCl} 150 ; \mathrm{KCl} 5$, Glucose 5, $\mathrm{MgCl}_{2} 1$ and HEPES 10, pH 7.4). In high $\mathrm{K}^{+}$stimulations, $50 \mathrm{mM} \mathrm{KCl}$ was added to the cells. The fluorescent measurements were performed using a dual-excitation fluorometer (SPEX, CM system) at 340 and $380 \mathrm{~nm}$ excitation and $505 \mathrm{~nm}$ emission. $\left[\mathrm{Ca}^{2+}\right]_{\mathrm{c}}$ was calculated using a fluorescence ratio at $340 \mathrm{~nm}$ excitation to that at $380 \mathrm{~nm}$ (Grynkiewicz et al., 1985). $R_{\max }$ was achieved by adding $0.01 \%$ digitonin to the cuvette at the end of experiments; excess EGTA was subsequently added to obtain $R_{\min }$. A $K_{\mathrm{d}}$ of $224 \mathrm{nM} \mathrm{Ca}^{2+}$ for fura-2 was used (Grynkiewicz et al., 1985; Vainio et al., 2000). Each data point were performed by five individual experiments in each protocol by using different cell batches and each experiment was carried out at least in duplicate.

\subsection{Electrophysiological measurements}

For whole-cell recording, the cell was whole-cell patch clamped as described before by Hamill et al. (1981). Patch pipettes were pulled from thin-wall capillaries with filament (Catalog 617000, A-M Systems Inc., WA, USA) using a two-stage microelectrode puller (P-97, Sutter Inc., USA), and fire-polished with a microforge
(MF-830, Narishige, Japan). When filled with pipette solution, the resistance ranged between 3 and $5 \mathrm{M} \Omega$. Ionic currents were measured from whole-cell patch-clamped cells using an EPC10 patch-clamp amplifier (HEKA GmbH, Germany) and controlled by Pulse (HEKA GmbH, Germany) program. To record the inward currents elicited by $10 \mu \mathrm{M}$ of EPI, cells were incubated in medium containing different concentrations of DBP and voltage-clamped at $-70 \mathrm{mV}$. The patch pipette was filled with a $\mathrm{K}^{+}$-containing solution (in $\mathrm{mM}$ ): $130 \mathrm{~K}$-aspartate, $20 \mathrm{KCl}, 1 \mathrm{MgCl}_{2}, 0.1 \mathrm{EGTA}, 3$ $\mathrm{Na}_{2} \mathrm{ATP}, 0.1 \mathrm{Na}_{2}$ GTP and 20 Hepes pH 7.3. EPI was puffed onto the patched cell from a micropipette with an opening diameter of about $1 \mu \mathrm{m}$ positioned at $10 \mu \mathrm{m}$ away from the cell for $1 \mathrm{~s}$ under the control of a picospritzer (General Valve, Fairfield, NJ).

\section{Results}

\subsection{Influence of DCB on induction of $\left[\mathrm{Ca}^{2+}\right]_{c}$ in $\mathrm{SH}-\mathrm{SY} 5 \mathrm{Y}$ cells}

DCB dose-dependently induced an increase of $\left[\mathrm{Ca}^{2+}\right]_{\mathrm{c}}$ that was sustained at a high level over a long period in human neuroblastoma SH-SY5Y cells in loading buffer containing $2.2 \mathrm{mM} \mathrm{CaCl}_{2}$ (Fig. 1). DCB $(500 \mu \mathrm{M})$ induced a net $\left[\mathrm{Ca}^{2+}\right]_{\mathrm{c}}$ increase of $191.6 \pm 29.8 \mathrm{nM}$ $(n=16)$. The elevation of $\left[\mathrm{Ca}^{2+}\right]_{c}$ might have been due to the intracellular release of $\mathrm{Ca}^{2+}$ from internal stores, or extracellular $\mathrm{Ca}^{2+}$ influx. Hence, the extracellular $\mathrm{Ca}^{2+}$ was depleted to exclude the possibility of extracellular $\mathrm{Ca}^{2+}$ influx. EGTA was added into the $\mathrm{Ca}^{2+}$ free loading buffer to chelate the extra $\mathrm{Ca}^{2+}$. In this case, DCB dose-dependently induced an increase in the $\left[\mathrm{Ca}^{2+}\right]_{c}$, followed by a quick decay in the absence of extracellular $\mathrm{Ca}^{2+}$ (Fig. 1). DCB $(500 \mu \mathrm{M})$ induced a net $\left[\mathrm{Ca}^{2+}\right]_{\mathrm{c}}$ increase of $60.67 \pm 9.33 \mathrm{nM}(n=8)$ in the absence of extracellular $\mathrm{Ca}^{2+}$. $\mathrm{Ca}^{2+}$ influx likely played a role in the DCB-induced $\left[\mathrm{Ca}^{2+}\right]_{c}$ peak because the $\left[\mathrm{Ca}^{2+}\right]_{\mathrm{c}}$ level was much higher in the presence of extracellular $\mathrm{Ca}^{2+}$ compared with that in a $\mathrm{Ca}^{2+}$-free buffer (Fig. 1).

Specific agonists and antagonists of mAChR, nAChR, and voltage-operated $\mathrm{Ca}^{2+}$ channels (VOCC) were used to determine if the DCB-induced increase of $\left[\mathrm{Ca}^{2+}\right]_{c}$ is coupled to these specific receptors or channels, since human SH-SY5Y cells possess mAChRs, nAChRs, and VOCC in their plasma membrane. An elevation of $\left[\mathrm{Ca}^{2+}\right]_{c}$ levels was obtained when the cells were stimulated with $0.3 \mathrm{mM}$ methacholine (a muscarinic receptor agonist) or $10 \mu \mathrm{M}$ epibatidine (a nicotinic receptor agonist) (Fig. 2). The methacholine-induced and epibatidine-induced increases of $\left[\mathrm{Ca}^{2+}\right]_{c}$ were completely inhibited by $20 \mu \mathrm{M}$ atropine or $100 \mu \mathrm{M}$ hexamethonium, respectively. A $\mathrm{KCl}$ level of $100 \mathrm{mM}$, which is known to elevate membrane potential by opening the voltagesensitive $\mathrm{Ca}^{2+}$ channels, caused an increase of $\left[\mathrm{Ca}^{2+}\right]_{\mathrm{c}}$ levels that was depressed by $0.1 \mathrm{mM}$ verapamil, a blocker of VOCC. The increase of $\left[\mathrm{Ca}^{2+}\right]_{\mathrm{c}}$ induced by $500 \mu \mathrm{M}$ DCB remained the same in the presence of $20 \mu \mathrm{M}$ atropine ( $104 \pm 15 \%$ of control, $n=3), 0.1 \mathrm{mM}$ hexamethonium ( $105 \pm 25 \%$ of control, $n=3)$, or $0.1 \mathrm{mM}$ verapamil $(114 \pm 27 \%$ of control, $n=6$ ) (Fig. 2).

\subsection{Effects of $D C B$ on $\mathrm{Ca}^{2+}$ signaling coupled with $n A C h R, m A C h R$ and VOCC}

To investigate the effects of DCB on acetylcholine receptors, we used carbachol to stimulate AChR in human neuroblastoma SHSY5Y cells. As shown in Fig. 3, the carbachol-induced $\left[\mathrm{Ca}^{2+}\right]_{\mathrm{c}}$ increase was inhibited by DCB in a dose-dependent manner ( $\left.\mathrm{IC}_{50}=161 \mu \mathrm{M}\right)$. DCB at $50 \mu \mathrm{M}$ significantly inhibited the carbachol-induced $\left[\mathrm{Ca}^{2+}\right]_{\mathrm{C}}$ rise ( $p<0.05$, paired t test comparing with control).

nAChRs and mAChRs differ in their signal transduction pathways: $n A C h R$ acts as a ligand-gated ion channel while intracellular $\mathrm{Ca}^{2+}$ release triggered by inositol triphosphate $\left(\mathrm{IP}_{3}\right)$ is associated with mAChR subtypes 3 and 5 (Zeng and Wess, 2000). To distinguish the inhibition of DCB on acetylcholine receptors, we used EPI and methacholine - specific ligands for $n A C h R$ and $m A C h R$, respectively - in our experiments. Fig. 3 shows that DCB dose- 

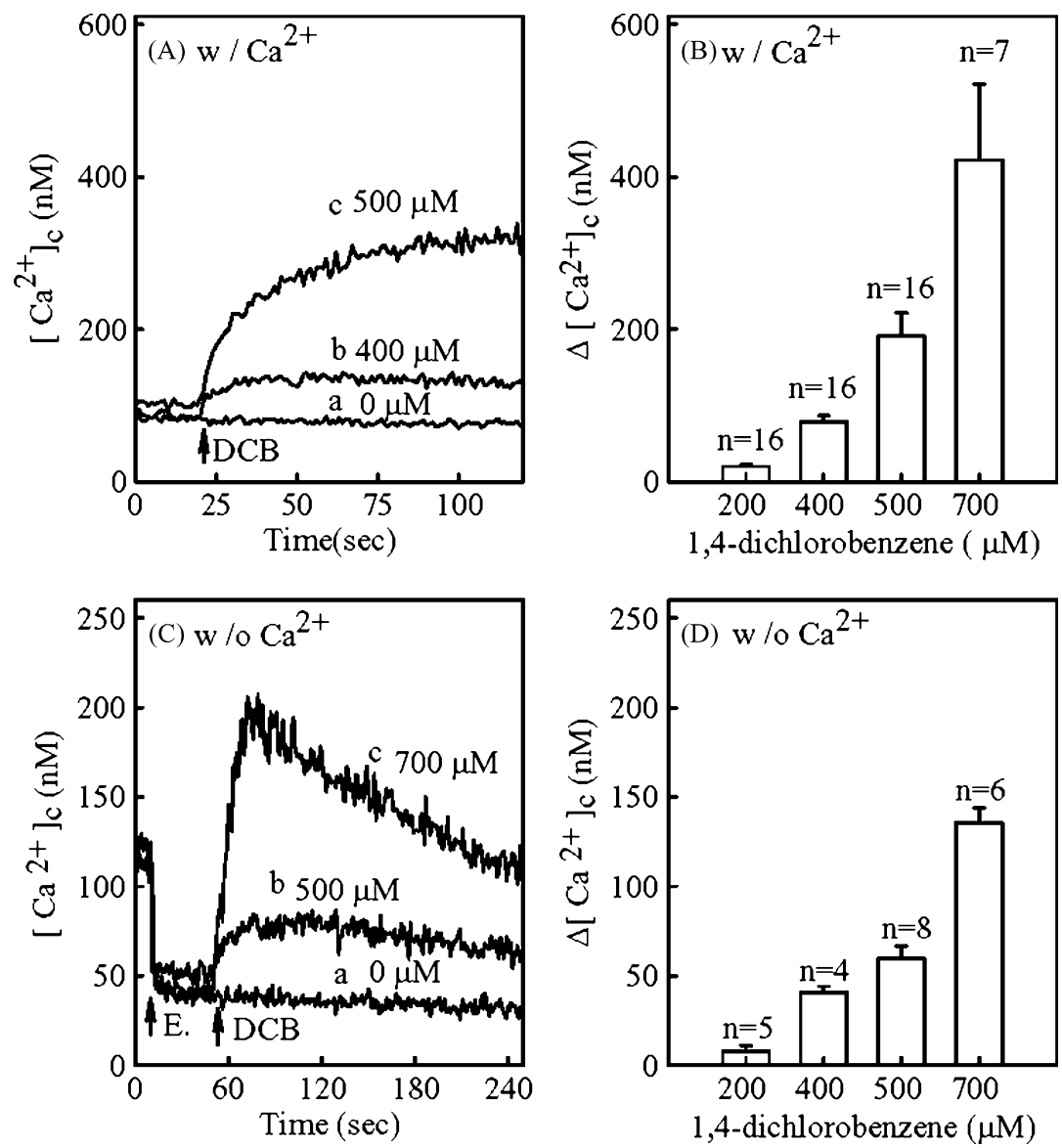

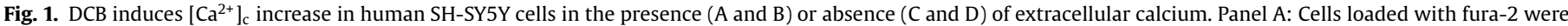

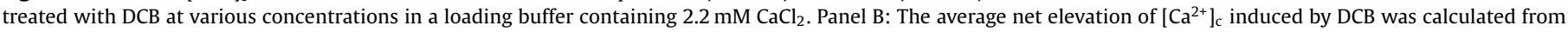

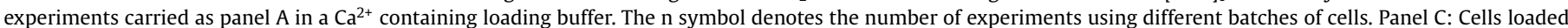

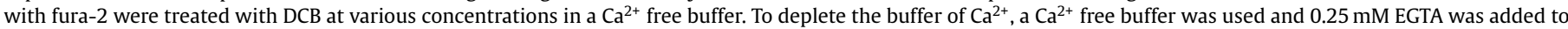
chelate extra $\mathrm{Ca}^{2+}$. Panel D: The average net elevation of $\left[\mathrm{Ca}^{2+}\right]_{\mathrm{c}}$ induced by DCB was calculated from experiments similar as panel $\mathrm{C}$ in a Ca ${ }^{2+}$ free loading buffer.

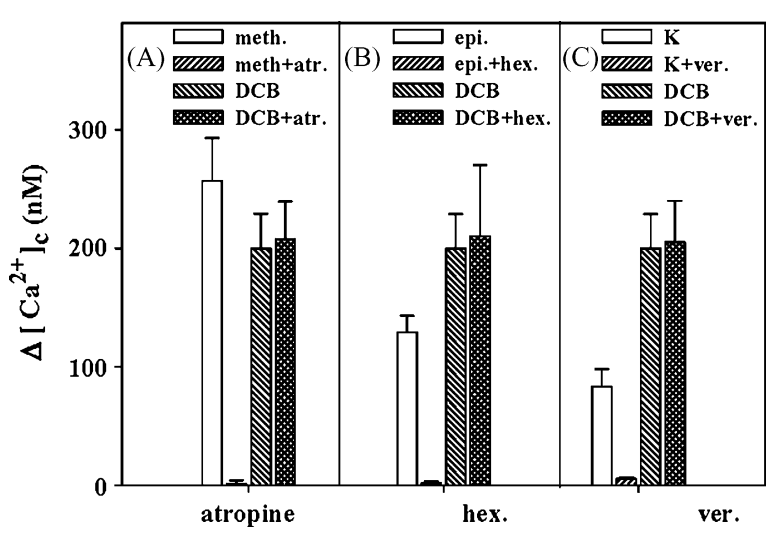

Fig. 2. The elevation level of $\left[\mathrm{Ca}^{2+}\right]_{c}$ induced by DCB remains in the presence of atropine, hexamethonium, or verapamil. Panel A: Cells loaded with fura-2 were stimulated with $0.3 \mathrm{mM}$ methacholine in the presence (right striated bars, meth. +atr.) or absence (open bars, meth.) of $20 \mu \mathrm{M}$ atropine. Cells were treated with $500 \mu \mathrm{M}$ DCB in the presence (double striated bars, DCB + atr.) or absence (left striated bars, DCB) of $20 \mu \mathrm{M}$ atropine. Panel B: Cells were stimulated with $10 \mu \mathrm{M}$ epibatidine in the presence (right striated bars, epi. + hex.) or absence (open bars, epi.) of $0.1 \mathrm{mM}$ hexamethonium. Cells were treated with $500 \mu \mathrm{M}$ DCB in the presence (double striated bars, DCB + hex.) or absence (left striated bars, DCB) of $0.1 \mathrm{mM}$ hexamethonium. Panel C: Cells were stimulated with $50 \mathrm{mM}$ high $\mathrm{K}$ solution in the presence (right striated bars, $\mathrm{K}+$ ver.) or absence (open bars, $\mathrm{K}$ ) of $0.1 \mathrm{mM}$ verapamil. Cells were treated with $500 \mu \mathrm{M} \mathrm{DCB}$ in the presence (double striated bars, DCB + ver.) or absence (left striated bars, DCB) of $0.1 \mathrm{mM}$ verapamil. dependently inhibited the EPI-induced $\left[\mathrm{Ca}^{2+}\right]_{\mathrm{c}}$ increase with an $\mathrm{IC}_{50}$ of $34 \mu \mathrm{M}$. At $50 \mu \mathrm{M}$, DCB had little discernable influence on basal $\left[\mathrm{Ca}^{2+}\right]_{c}$ but significantly inhibited EPI-induced $\left[\mathrm{Ca}^{2+}\right]_{c}$ increase (inhibitory rate $53.37 \pm 6.95 \%, n=8$ ). The inhibition of $17 \alpha$-estradiol on the EPI-induced $\left[\mathrm{Ca}^{2+}\right]_{\mathrm{c}}$ increase was also found with an $\mathrm{IC}_{50}$ as $6.5 \mu \mathrm{M}$ (data not shown). Moreover, DCB dose-dependently inhibited the methacholine-induced $\left[\mathrm{Ca}^{2+}\right]_{\mathrm{c}}$ rise with an $\mathrm{IC}_{50}$ of $294 \mu \mathrm{M}$ (Fig. 4). At $100 \mu \mathrm{M}, \mathrm{DCB}$ slightly inhibited the methacholineinduced $\left[\mathrm{Ca}^{2+}\right]_{c}$ increase (inhibitory rate $21.14 \pm 2.08 \%$ of control, $n=8$ ), but exerted a more marked inhibitions on $n A C h R$.

To determine if DCB interacts with voltage-operated $\mathrm{Ca}^{2+}$ channel, we examined the effects of DCB on the KCl-induced $\left[\mathrm{Ca}^{2+}\right]_{c}$ increase. As shown in Fig. 4, $50 \mu \mathrm{M}$ DCB inhibited the $\mathrm{KCl}$-induced $\left[\mathrm{Ca}^{2+}\right]_{\mathrm{c}}$ increase (inhibitory rate $20.8 \pm 5.2 \%$ of control, $\left.n=4\right)$. DCB at $400 \mu \mathrm{M}$ totally inhibited the $\mathrm{KCl}$-induced $\left[\mathrm{Ca}^{2+}\right]_{c}$ increase. A DCB $\mathrm{IC}_{50}$ of $165 \mu \mathrm{M}$ was necessary to inhibit the $\mathrm{KCl}$-induced $\left[\mathrm{Ca}^{2+}\right]_{\mathrm{C}}$ increase.

\subsection{Effects of $D C B$ on $\mathrm{Ca}^{2+}$ signaling coupled with intracellular $\mathrm{Ca}^{2+}$ release}

Effects of DCB on endoplasmic reticulum $\mathrm{Ca}^{2+}$ stores were investigated. Thapsigargin is a well-known inhibitor of endoplasmic reticulum $\mathrm{Ca}^{2+}$-ATPase. The stimulation of thapsigargin induced a rise in $\left[\mathrm{Ca}^{2+}\right]_{c}$ (Fig. 5A). The cells were treated with DCB at various concentrations for $10 \mathrm{~min}$ and then stimulated with thap- 

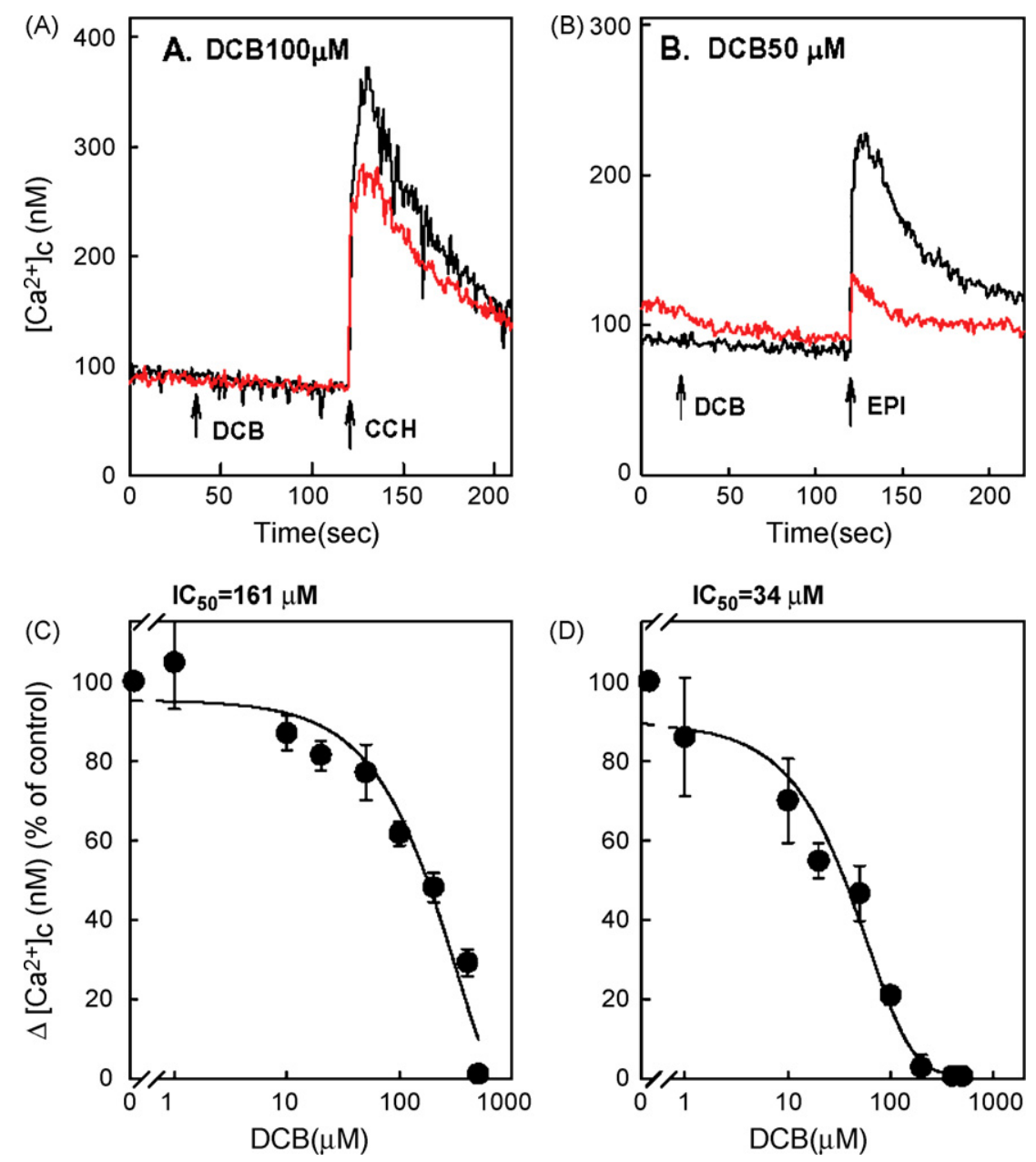

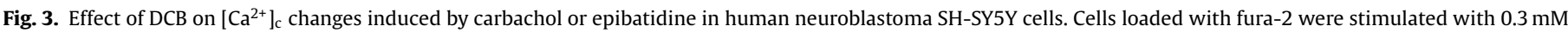

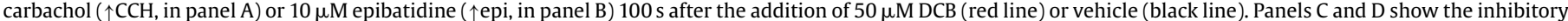

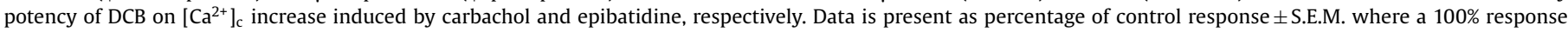

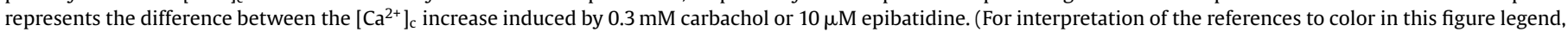
the reader is referred to the web version of the article.)

sigargin. The stimulation of thapsigargin could not induce further $\mathrm{Ca}^{2+}$ release from endoplasmic reticulum in the cells pretreated with DCB at concentrations above $400 \mu \mathrm{M}$, but thapsigargin still evoked a $\left[\mathrm{Ca}^{2+}\right]_{\mathrm{C}}$ increase after pretreatment with DCB concentrations of 100 or $200 \mu \mathrm{M}$ (Fig. 5B-E). Moreover, DCB was still capable to induce a rise in $\left[\mathrm{Ca}^{2+}\right]_{\mathrm{c}}$ after the cells pretreated with thapsigargin for $10 \mathrm{~min}$ (Fig. $5 \mathrm{~F}$ ).

The effects of thapsigargin on the $\left[\mathrm{Ca}^{2+}\right]_{c}$ increase induced by epibatidine and methacholine were investigated. Thapsigargin inhibited the $\left[\mathrm{Ca}^{2+}\right]_{c}$ rise induced by methacholine (Fig. 6). We integrated the peak area (150 s) under the stimulation of epibatidine or methacholine and found thapsigargin, at $2.5 \mu \mathrm{M}$, inhibited the peak induced by epibatidine and methacholine from $100 \%$ peak area to 74 and 3\% peak area, respectively.

\subsection{Effects of DCB on electrophysiological changes under the stimulation of $n A C h R$}

The earlier results suggest that DCB acts on the nAChR. To further confirm that DCB inhibited the EPI-induced $\mathrm{Ca}^{2+}$ signals occurred directly by its effects on the nAChR, the inward current upon stimulation of nAChR by EPI was recorded. Fig. 7A shows the representative current traces from a voltage clamped cell stimulated by $10 \mu \mathrm{M}$ EPI for $0.2 \mathrm{~s}$ in the absence or presence of 100 or
$500 \mu \mathrm{M}$ DCB. DCB inhibited the EPI-induced inward current. Fig. 7B shows the averaged total influx current under the stimulation of nAChR by EPI. DCB significantly blocked the EPI-induced influx current. The results illustrate that DCB exerts its effect directly on the nAChR.

\section{Discussion}

In this study, we found several novel characteristics of DCB modulate neuronal $\left[\mathrm{Ca}^{2+}\right]_{c}$ homeostasis. Firstly, DCB induces a $\left[\mathrm{Ca}^{2+}\right]_{c}$ elevation and the source of $\mathrm{Ca}^{2+}$ including extracellular $\mathrm{Ca}^{2+}$ influx and intracellular $\mathrm{Ca}^{2+}$ release. A rise in $\left[\mathrm{Ca}^{2+}\right]_{c}$ was observed after the addition of DCB in a buffer with or without $\mathrm{Ca}^{2+}$ (Fig. 1). Secondly, DCB inhibited the $\mathrm{Ca}^{2+}$ signaling coupled with the stimulation of AChRs including nAChRs and mAChRs, as evidenced by the inhibition of DCB in the $\left[\mathrm{Ca}^{2+}\right]_{c}$ increase induced by carbachol, epibatidine, and methacholine. The inhibition of DCB on the activities of nAChR was also demonstrated by the electrophysiological measurements. The influx current coupled with nAChR can be blocked by DCB. Thirdly, DCB inhibited the $\mathrm{Ca}^{2+}$ signaling coupled with the $\mathrm{K}^{+}$-mediated activation of VOCC. The data reveals that DCB potently interferes with $\left[\mathrm{Ca}^{2+}\right]_{c}$ homeostasis and the functional activities of AChRs and VOCCs in human neuroblastoma SH-SY5Y cells. As far as we 

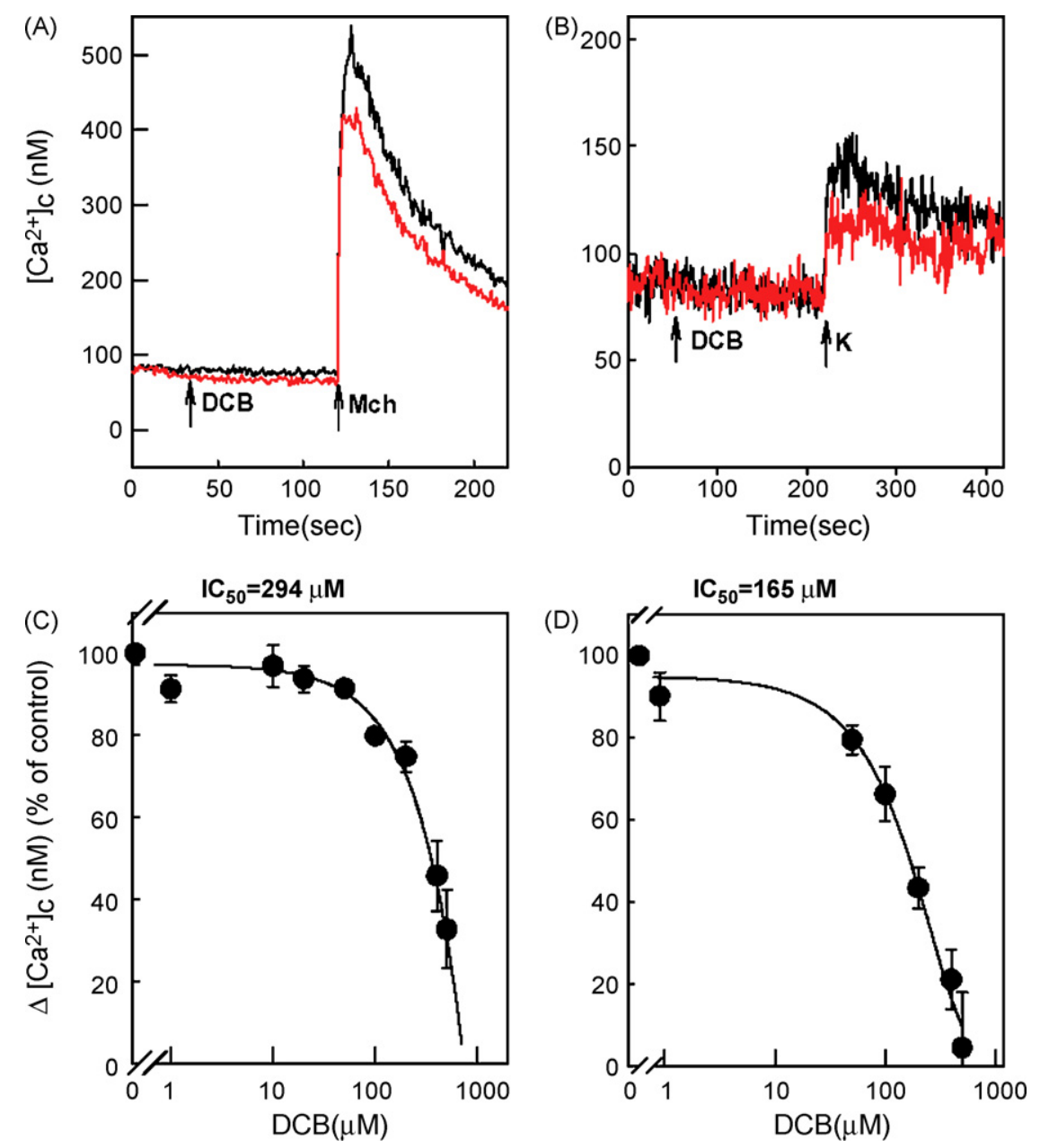

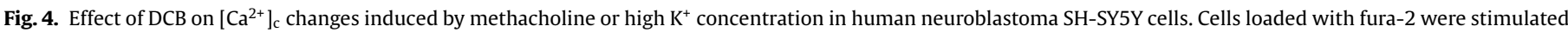

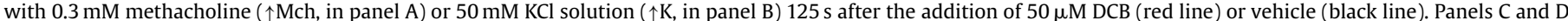

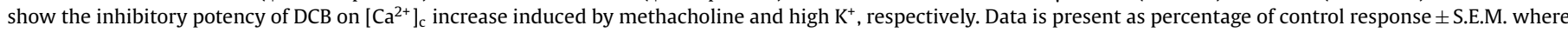

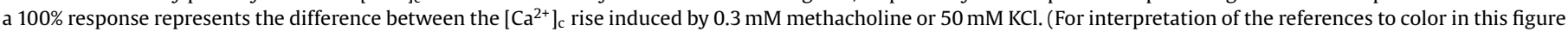
legend, the reader is referred to the web version of the article.)

know, this is the first description of these three characteristics of DCB.

Precise regulation of $\mathrm{Ca}^{2+}$ homeostasis is essential to cellular functions and viability. We used thapsigargin as a tool to study the roles of DCB in the modulation of intracellular $\mathrm{Ca}^{2+}$ homeostasis. Our data shows that thapsigargin could not totally inhibit the DCB-induced $\left[\mathrm{Ca}^{2+}\right]_{c}$ rise. We suggest that $\mathrm{DCB}$ induces $\mathrm{Ca}^{2+}$ release not only from thapsigargin-sensitive intracellular $\mathrm{Ca}^{2+}$ stores, but also from other thapsigargin-insensitive intracellular $\mathrm{Ca}^{2+}$ stores. However, DCB could completely deplete the $\mathrm{Ca}^{2+}$ stored in the endoplasmic reticulum, as shown by the lack of thapsigargin response after the pretreatment of DCB. Nonylphenol, an endocrine disruptor with estrogen-like activities, is an inhibitor of the endoplasmic reticulum $\mathrm{Ca}^{2+}$-pump (Michelangeli et al., 1990). DCB has estrogenlike activities (Versonnen et al., 2003). Although estradiol has no such propensity to raise $\left[\mathrm{Ca}^{2+}\right]_{c}$, DCB acts similarly to nonylphenol in releasing $\mathrm{Ca}^{2+}$ from the endoplasmic reticulum. Although the $\mathrm{Ca}^{2+}$ releasing characteristic of DCB is evidenced in this study, the possibility of $\mathrm{DCB}$ acting on the endoplasmic reticulum membrane needs further study.

Presently, we show that DCB can inhibit the $\mathrm{Ca}^{2+}$ signaling of AChRs including nAChR and mAChR. SH-SY5Y neuroblastoma cells predominantly possess $\mathrm{mAChR}$ subtype 3 , which links with the activation of phospholipase $\mathrm{C}$ and the production of $\mathrm{IP}_{3}$ which triggers internal $\mathrm{Ca}^{2+}$ release (Koenig and Edwardson, 1996). The inhibition capability of DCB might come from its $\mathrm{Ca}^{2+}$ releasing character. In order to clarify this, we observed the inhibition capability of thapsigargin. Thapsigargin at $2.5 \mu \mathrm{M}$ almost depleted the $\mathrm{Ca}^{2+}$ stored in the endoplasmic reticulum and inhibited $97 \%$ of the methacholine-induced $\mathrm{Ca}^{2+}$ peak. DCB inhibited the internal thapsigargin-sensitive $\mathrm{Ca}^{2+}$ pools in a dose-dependent manner. DCB at $300 \mu \mathrm{M}$ DCB inhibited by $50 \%$ the thapsigargin-sensitive $\mathrm{Ca}^{2+}$ pools. The $\mathrm{IC}_{50}$ of $\mathrm{DCB}$ on methacholine-induced $\left[\mathrm{Ca}^{2+}\right]_{\mathrm{c}}$ increase was $294 \mu \mathrm{M}$. We predict the $\mathrm{Ca}^{2+}$-releasing character of DCB plays an important role in its inhibition of $M A C h R$. DCB has a stronger inhibition on $\mathrm{nAChR}$ than on $\mathrm{mAChR}$. However, thapsigargin only has a very smaller inhibition on $\mathrm{nAChR}$. We predict that the inhibition of DCB on $\mathrm{AAChR}$ is related not only to the characteristics of $\mathrm{DCB}$ releasing $\mathrm{Ca}^{2+}$ from endoplasmic reticulum but to other characteristics of DCB.

Based on the present observations, we suggest three routes are responsible for DCB inhibition of $\mathrm{nAChR} \mathrm{Ca}^{2+}$ signaling. First, DCB acts as a channel inhibitor to block the nAChR ion channel. This characteristic might arise from its estrogenic-like activities (Versonnen et al., 2003). Estradiol and other steroid hormones are able to alter neuronal excitability by augmenting or inhibiting neurotransmitter-activated responses mediated via receptor-gated ion channels (Chen and Farese, 1999; Arias, 1998). Estradiol as 


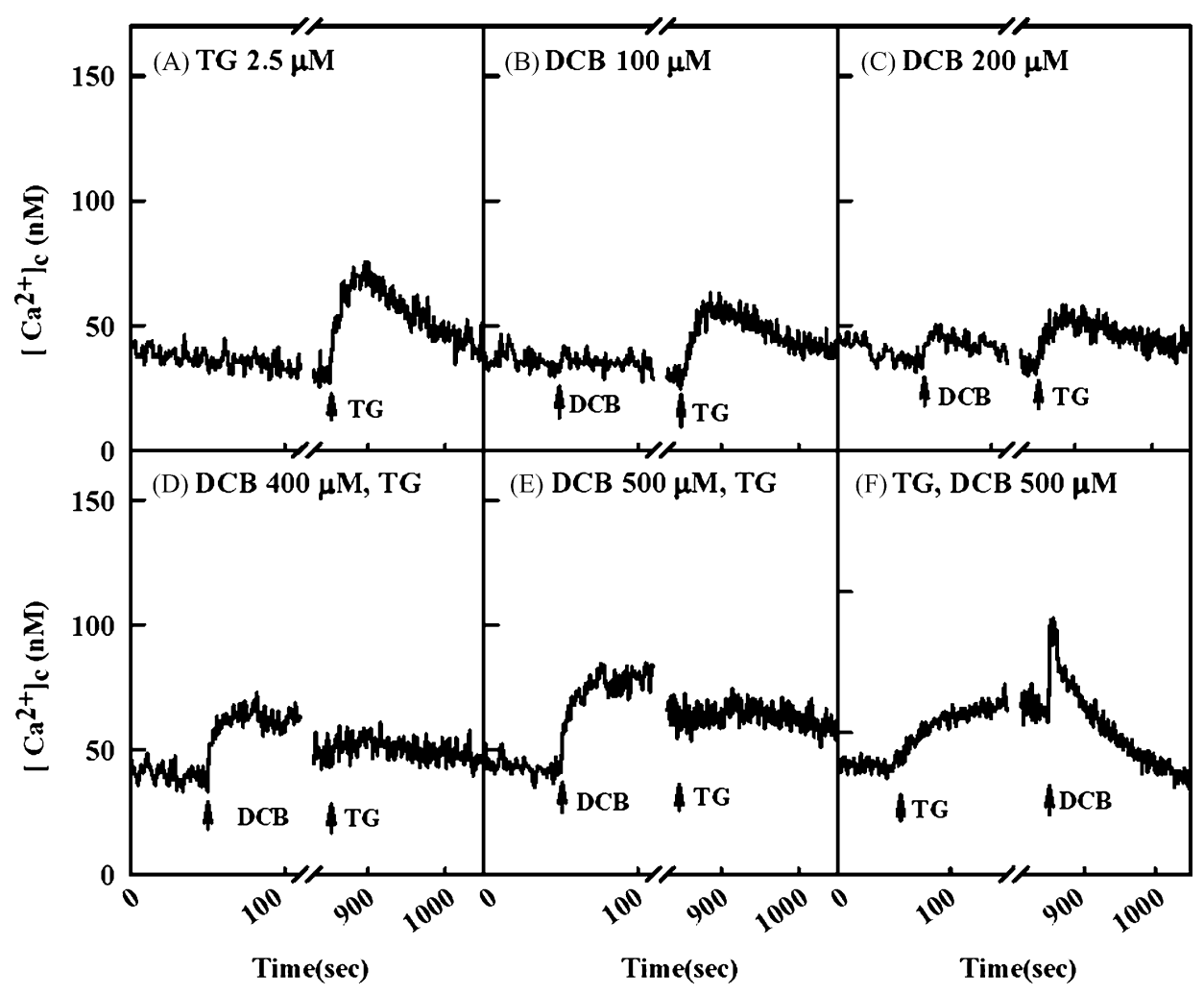

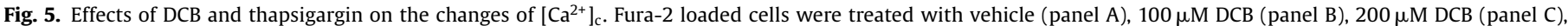

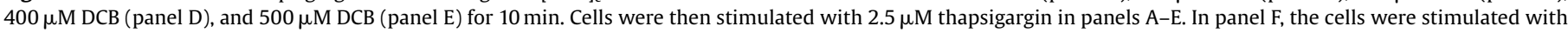
$2.5 \mu \mathrm{M}$ thapsigargin for $10 \mathrm{~min}$, then stimulated with $500 \mu \mathrm{M}$ DCB.

(A) EPI

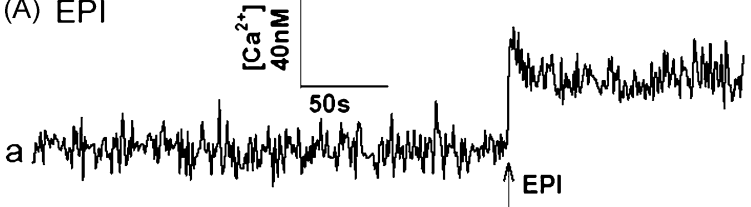

b

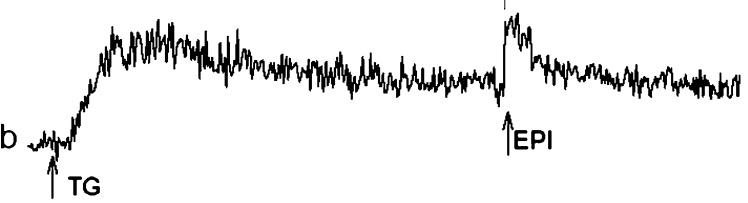

(B) Mch

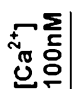

a
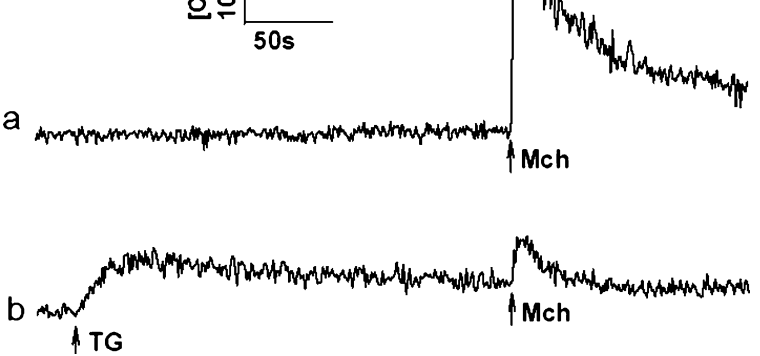

Fig. 6. Effect of thapsigargin on $\left[\mathrm{Ca}^{2+}\right]_{c}$ changes induced by epibatidine or methacholine in human neuroblastoma SH-SY5Y cells. Cells loaded with fura-2 were stimulated with $10 \mu \mathrm{M}$ epibatidine ( $\uparrow \mathrm{EPI}$, in panel A) or $0.3 \mathrm{mM}$ methacholine ( $\uparrow$ Mch, in panel B) $270 \mathrm{~s}$ after the addition of $2.5 \mu \mathrm{M}$ thapsigargin (line b) or vehicle (line a).
(A) $\mathrm{E}$
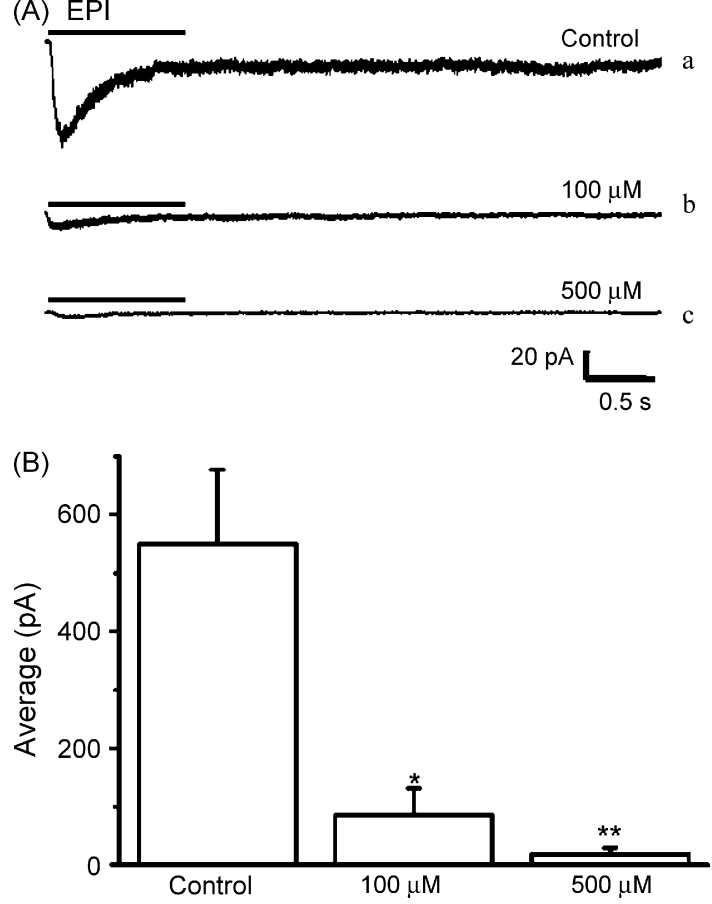

Fig. 7. EPI-induced inward current was inhibited by DCB. The cell was voltageclamped in order to record whole-cell current. Panel A: Using ejection pipette, $10 \mu \mathrm{M}$ EPI was applied to the clamped cell in the absence (trace a) or presence of $0.1 \mathrm{mM}$ DCB (trace b) or $0.5 \mathrm{mM}$ DCB (trace c). Panel B: The total current influx induced by $10 \mu \mathrm{M}$ EPI in loading buffer (LB) with DCB at various concentrations. Data are collected from two batches cells $(n=12-18) .{ }^{*} P<0.01$, paired $t$-test comparing with control (loading buffer). 
well as other steroids such as progesterone inhibit ${ }^{86} \mathrm{Rb}^{+}$efflux induced by carbachol in both human neuronal and muscle cell lines expressing $\alpha 1 \beta 1 \gamma \delta$-nAChRs and $\alpha 3 \beta 4$-nAChRs (Ke and Lukas, 1996). We found that DCB was also potent in inhibiting $\mathrm{Ca}^{2+}$ signaling of nAChRs. nAChRs are allosteric proteins whose functional activities are affected by functional state transitions, which can be determined by agonists and competitive antagonists that bind to acetylcholine binding sites, as well as by non-competitive inhibitors having two distinctive sites-one high- and one lowaffinity (Changeux et al., 1984). Steroid compounds address a hydrophobic interaction at the low-affinity binding site (Arias, 1998). We predict that one of the mechanisms of DCB's inhibition of $\mathrm{nAChRs}$ is its action on the steroid binding sites of nAChRs as a steroid-compound channel blocker.

Secondly, DCB acted on VOCC as a inhibitor, evidenced by its inhibition of the high $\mathrm{K}^{+}$-induced $\left[\mathrm{Ca}^{2+}\right]_{\mathrm{c}}$ increase (Fig. 4). Because a high $\mathrm{K}^{+}$concentration bypasses the receptor and directly depolarizes the plasma membrane, the inhibitory action of DCB is not limited to the nAChR level, but also occurs at some step following plasma membrane depolarization. The non-genomic modulation of membrane channels by estrogen has previously been discussed (Zhang et al., 1994; Kim et al., 2000). Our results show that DCB inhibits VOCCs. We suggest that DCB with membrane-mediated non-genomic estrogenic characteristics is capable of altering the functional activities of nAChR channels and VOCCs; thus, the inhibition of DCB on the $\mathrm{Ca}^{2+}$ signaling coupled with $\mathrm{nAChR}$ is higher than its inhibition of $\mathrm{mAChR}$.

Thirdly, the inhibition of the $\mathrm{Ca}^{2+}$ signaling coupled with nAChRs could possibly be through $\mathrm{Ca}^{2+}$-induced $\mathrm{Ca}^{2+}$ release (CICR). DCB could deplete the stored $\mathrm{Ca}^{2+}$ in the endoplasmic reticulum so that no $\mathrm{Ca}^{2+}$ can be released from the stimulated endoplasmic reticulum. During stimulation, a small amount of $\mathrm{Ca}^{2+}$ influx can initiate CICR by opening ryanodine receptors that are sensitive to a slight elevation in $\left[\mathrm{Ca}^{2+}\right]_{\mathrm{c}}$ (Lemmens et al., 2001). $\mathrm{Ca}^{2+}$ influx coupled with the stimulation of nAChRs can further induce CICR from ER and the decrease of $\mathrm{Ca}^{2+}$ stored content in endoplasmic reticulum can inhibit the $\mathrm{Ca}^{2+}$ signaling coupled with nAChRs (Pan et al., 2006). We suggest that the presently observed inhibition by DCB of nAChRs is partially due to its depletion of the intracellular $\mathrm{Ca}^{2+}$ stores so that stimulation of nAChRs cannot evoke CICR in the presence of DCB. The involvement of all three routes allows DCB to inhibit the $\mathrm{Ca}^{2+}$ signaling coupled with nAChRs at the concentration lower than DCB's actions on mAChR.

DCB presently interfered with $\mathrm{Ca}^{2+}$ homeostasis in vitro at $\mu \mathrm{M}$ concentrations. Could this situation occur physiologically? Previous studies have determined that the plasma concentration of DCB (one day after DCB feeding) is $28 \mu \mathrm{g} / \mathrm{ml}$ and its metabolite dichlorophenol was $26 \mu \mathrm{g} / \mathrm{ml}$; the concentration of DCB in hepatic tissue was $67 \mu \mathrm{g} / \mathrm{g}$ and in adipose tissue was $50 \mu \mathrm{g} / \mathrm{g}$ (Bomhard et al., 1998). The molecular weight of DCB is 167. Thus, the concentrations of DCB in plasma, hepatic tissue, and adipose tissue, based on the above observations, are $168 \mu \mathrm{M}$ in plasma, $401 \mu \mathrm{M}$ in hepatic tissue, and $299 \mu \mathrm{M}$ in adipose tissue. Since DCB could exist in high concentration in these situations, we suggest that DCB interference with $\mathrm{Ca}^{2+}$ homeostasis is conceivable in vitro and in vivo. Further study of $\mathrm{DCB}$ on neuronal activities in animal models is required to directly link human exposure to DCB and the interference of DCB on $\mathrm{Ca}^{2+}$ homeostasis.

Steroid hormones affect developmental processes and are involved in biological responses to homeostatic challenges. Estrogen in particular plays roles in differentiation, proliferation, homeostasis, and reproductive functions. In addition to traditional genomic effects mediated via receptors in nucleus, steroid hormones exert non-genomic membrane effects via membrane ion channels. Some neuronal receptors belong to an ion channel recep- tor superfamily and serve as additional potential addressing sites for steroid hormones. These neuronal receptors, which appear during embryonic stages, act as putative guidelines for animal differentiation (Chen and Farese, 1999).

In this study, we describe novel characteristics of DCB, acting as AChR inhibitors and interfering $\mathrm{Ca}^{2+}$ homeostasis. This suggests that DCB might obstruct animal homeostasis and neuronal signaling.

\section{Conflict of interest}

None.

\section{Acknowledgements}

We wish to thank Mr. Jone Lindemann for help editing this manuscript. This study was supported by grants from the National Science Council, Taiwan, ROC (NSC-96-2745-B-031-005-URD, and NSC-96-2621-Z-031-001).

\section{References}

Arias, H.R., 1998. Noncompetitive inhibition of nicotinic acetylcholine receptors by endogenous molecules. J. Neurosci. Res. 52, 369-379.

Bahrami, F., Brittebo, E.B., Bergman, A., Larsson, C., Brandt, I., 1999. Localization and comparative toxicity of methylsulfonyl-2,5- and 2,6-dichlorobenzene in the olfactory mucosa of mice. Toxicol. Sci. 49, 116-123.

Belmonte, K.E., 2005. Cholinergic pathways in the lungs and anticholinergic therapy for chronic obstructive pulmonary disease. Proc. Am. Thorac. Soc. 2, 297-304

Bomhard, E.M., Schmidt, U., Löser, E., 1998. Time course of enzyme induction in liver and kidneys and absorption, distribution and elimination of 1,4dichlorobenzene in rats. Toxicology 131, 73-91.

Cardoso, C.C., Pereira, R.T., Koyama, C.A., Porto, C.S., Abdalla, F.M., 2004. Effects of estrogen on muscarinic acetylcholine receptors in the rat hippocampus. Neuroendocrinology $80,379-386$.

Carlsson, C., Fredriksson, A., Brandt, I., 2003. 2,6-Dichlorophenyl methylsulphone induced behavioral impairments in rats and mice in relation to olfactory mucosa metaplasia. Pharmacol. Toxicol. 93, 156-168.

Changeux, J.P., Devillers-Thiéry, A., Chemouilli, P., 1984. Acetylcholine receptor: an allosteric protein. Science 225, 1335-1345.

Chen, H.C., Farese, R.V., 1999. Steroid hormones: interactions with membrane-bound receptors. Curr. Biol. 9, R478-R481.

Grant, M.P., Landis, S.C., 1991. Developmental expression of muscarinic cholinergic receptors and coupling to phospholipase $C$ in rat sweat glands are independent of innervation. J. Neurosci. 11, 3772-3782.

Grynkiewicz, G., Poenie, M., Tsien, R.Y., 1985. A new generation of $\mathrm{Ca}^{2+}$ indicators with greatly improved fluorescence properties. J. Biol. Chem. 260, 3440-3450.

Hamassaki-Britto, D.E., Gardino, P.F., Hokoç, J.N., Keyser, K.T., Karten, H.J., Lindstrom, J.M., Britto, L.R., 1994. Differential development of alpha-bungarotoxin-sensitive and alpha-bungarotoxin-insensitive nicotinic acetylcholine receptors in the chick retina. J. Comp. Neurol. 347, 161-170.

Hamill, O.P., Marty, A., Neher, E., Sakmann, B., Sigworth, F.J., 1981. Improved patchclamp techniques for high-resolution current recording from cells and cell-free membrane patches. Pflugers Arch. 391, 85-100.

Hartwell, T.D., Perritt, R.L., Pellizzari, E.D., Michael, L.C., 1992. Results from the 1987 total exposure assessment methodology (TEAM) study in southern California. Atmos. Environ. 26A, 1519-1527.

Hayes, W.J., 1982. Pesticide Studied in Man. Williams and Wilkins, Baltimore, MD pp. $163-165$.

Hill, R.H., Ashley, D.L., Head, S.L., Needham, L.L., Pirkle, J.L., 1995. p-Dichlorobenzene exposure among 1000 adults in the United States. Arch. Environ. Health 50, 277-280.

(International Agency for Research on Cancer) IARC, 1982. Orthoand pdichlorobenzenes. IARC Monogr. Eval. Carcinog. Risk Chem. Hum. 29, 213-238.

Jan, J., 1983. Chlorobenzene residues in human fat and milk. Bull. Environ. Contam. Toxicol. 30, 595-599.

Ke, L., Lukas, R.J., 1996. Effects of steroid exposure on ligand binding and functional activities of diverse nicotinic acetylcholine receptor subtypes. J. Neurochem. 67, 1100-1112.

Kelly, M.J., Levin, E.R., 2001. Rapid actions of plasma membrane estrogen receptors Trends Endocrinol. Metab. 12, 152-156.

Kim, Y.J., Hur, E.M., Park, T.J., Kim, K.T., 2000. Nongenomic inhibition of catecholamine secretion by $17 \beta$-estradiol in PC12 cells. J. Neurochem. 74 , 2490-2496.

Koenig, J.A., Edwardson, J.M., 1996. Intracellular trafficking of the muscarinic acetylcholine receptor: importance of subtype and cell type. Mol. Pharmacol. 49, 351-359. 
R.-M. Yan et al. / Toxicology 253 (2008) 28-35

35

Kostiainen, R., 1995. Volatile organic compounds in the indoor air of normal and sick houses. Atmos. Environ. 29, 693-702.

Lambert, D.G., Whitham, E.M., Baird, J.G., Nahorski, S.R., 1990. Different mechanisms of $\mathrm{Ca}^{2+}$ entry induced by depolarization and muscarinic receptor stimulation in SH-SY5Y human neuroblastoma cells. Brain Res. Mol. Brain Res. 8, 263-266.

Lemmens, R., Larsson, O., Berggren, P.O., Islam, M.S., 2001. $\mathrm{Ca}^{2+}$-induced $\mathrm{Ca}^{2+}$ release from the endoplasmic reticulum amplifies the $\mathrm{Ca}^{2+}$ signal mediated by activation of voltage-gated L-type $\mathrm{Ca}^{2+}$ channels in pancreatic beta-cells. J. Biol. Chem. 276, 9971-9977.

Liu, P.S., Lin, C.M., 2002. Phthalates suppress the calcium signaling of nicotinic acetylcholine receptors in bovine adrenal chromaffin cells. Toxicol. Appl. Pharmacol. 183, 92-98.

Lukas, R.J., Norman, S.A., Lucero, L., 1993. Characterization of nicotinic acetylcholine receptors expressed by cells of the SH-SY5Y human neuroblastoma clone line. Mol. Cell Neurosci. 4, 1-12.

Michelangeli, F., Orlowski, S., Champeil, P., East, J.M., Lee, A.G., 1990. Mechanism of inhibition of the $\left(\mathrm{Ca}^{2+}-\mathrm{Mg}^{2+}\right)$-ATPase by nonylphenol. Biochemistry 29 3091-3101.

Morita, M., Ohi, G., 1975. para-Dichlorobenzene in human tissue and atmosphere in Tokyo metropolitan area. Environ. Pollut. 8, 269-274.

(National Toxicology Program) NTP, 1987. Toxicology and carcinogenesis studies of 1,4-dichlorobenzene in F344/N rats and B6C3F1 mice (gavage studies). Natl. Toxicol. Program. Tech. Rep. Ser. 319, 1-198.

Pan, C.Y., Huang, C.H., Lee, C.H., 2006. Calcium elevation elicited by reverse mode $\mathrm{Na}^{+} / \mathrm{Ca}^{2+}$ exchange activity is facilitated by intracellular calcium stores in bovine chromaffin cells. Biochem. Biophys. Res. Commun. 42, 589-595.

Passafaro, M., Clementi, F., Sher, E., 1992. Metabolism of $\omega$-conotoxin-sensitive voltage-operated calcium channels in human neuroblastoma cells: modulation by cell differentiation and anti-channel antibodies. J. Neurosci. 12, 3372-3379.
Sastry, B.V., Sadavongvivad, C., 1978. Cholinergic systems in non-nervous tissues. Pharmacol. Rev. 30, 65-132.

Steinmetz, K.L., Bakke, J.P., Hamilton, C.M., Pardo, K.C., Ramsey, M., Mirsalis, J.C. 1988. Evaluation of unscheduled DAN synthesis (UDS) and S-phase synthesis (SPS) following treatment with $p$-dichlorobenzene. Toxicologist 8, 160.

Toselli, M., Masetto, S., Rossi, P., Taglietti, V., 1991. Characterization of a voltage dependent calcium current in the human neuroblastoma cell line SH-SY5Y during differentiation. Eur. J. Neurosci. 3, 514-522.

Vainio, P.J., Tornquist, K., Tuominen, R.K., 2000. Cotinine and nicotine inhibit each other's calcium responses in bovine adrenal chromaffin cells. Toxicol. Appl. Pharmacol. 163, 183-187.

Versonnen, B.J., Arijs, K., Verslycke, T., Lema, W., Janssen, C.R., 2003. In vitro and in vivo estrogenicity and toxicity of $o-, m$-, and $p$-dichlorobenzene. Environ. Toxicol. Chem. 22, 329-335.

Wallace, L.A., Pellizzari, E.D., Hartwell, T.D., Davis, V., Michael, L.C., Whitmore, R.W., 1989. The influence of personal activities on exposure to volatile organic compounds. Environ. Res. 50, 37-55.

Wallace, L.A., Pellizzari, E.D., Hartwell, T.D., Sparacino, C., Whitmore, R., Sheldon, L., Zelon, H., Perritt, R., 1987. The TEAM (Total Exposure Assessment Methodology) Study: personal exposures to toxic substances in air, drinking water, and breath of 400 residents of New Jersey, North Carolina, and North Dakota. Environ. Res. 43, 290-307.

Wallace, L.A., Pellizzari, E.D., Hartwell, T.D., Whitmore, R., Zelon, H., Perritt, R., Sheldon, L., 1988. The California TEAM study: breath concentrations and personal exposures to 26 volatile compounds in air and drinking water of 188 residents of Los Angeles, Antioch, and Pittsburg, CA. Atmos. Environ. 22, 2141-2163.

Zeng, F., Wess, J., 2000. Molecular aspects of muscarinic receptor dimerization. Neuropsychopharmacology 23, S19-S31.

Zhang, F., Ram, J.L., Standley, P.R., Sowers, J.R., 1994. 17beta-Estradiol attenuates voltage-dependent $\mathrm{Ca}^{2+}$ currents in A7r5 vascular smooth muscle cell line. Am. J. Physiol. Cell. Physiol. 266, C975-C980. 